\title{
Shrimp pathogenicity, hemolysis, and the presence of hemolysin and TTSS genes in Vibrio harveyi isolated from Thailand
}

\author{
Pimonsri Rattanama ${ }^{1,2}$, Kanchana Srinitiwarawong ${ }^{1}$, Janelle R. Thompson ${ }^{3}$, \\ Rattanaruji Pomwised ${ }^{1}$, Kidchakarn Supamattaya ${ }^{4}$, Varaporn Vuddhakul ${ }^{1, *}$ \\ ${ }^{1}$ Department of Microbiology, Faculty of Science, Prince of Songkla University, Hat Yai, 90112 Songkhla, Thailand \\ ${ }^{2}$ Department of Biomedical Science, Faculty of Medicine, Prince of Songkla University, Hat Yai, 90112 Songkhla, Thailand \\ ${ }^{3}$ Department of Civil and Environmental Engineering, Massachusetts Institute of Technology, 15 Vassar Street, \\ Cambridge, Massachusetts 02139, USA \\ ${ }^{4}$ Department of Aquatic Animal Science, Faculty of Natural Resources, Prince of Songkla University, Hat Yai, \\ 90112 Songkhla, Thailand
}

\begin{abstract}
The virulence factors of Vibrio harveyi, the causative agent of luminous vibriosis, are not completely understood. We investigated the correlations between shrimp mortality, hemolysis, the presence of a hemolysin gene (vhh), and a gene involved in the type III secretion system (the Vibrio calcium response gene vcrD). $V$. harveyi HY01 was isolated from a shrimp that died from vibriosis, and 36 other $V$. harveyi isolates were obtained from fish and shellfish in Hat Yai city, Thailand. An ocean isolate of $V$. harveyi BAA-1116 was also included. Thirteen isolates including $V$. harveyi HY01 caused shrimp death $12 \mathrm{~h}$ after injection. Most $V$. harveyi isolates in this group (designated as Group A) caused hemolysis on prawn blood agar. None of the shrimp died after injection with $V$. harveyi BAA-1116. Molecular analysis of all $V$. harveyi isolates revealed the presence of $v c r D$ in both pathogenic and non-pathogenic strains. Although vhh was detected in all $V$. harveyi isolates, some isolates did not cause hemolysis, indicating that vhh gene expression might be regulated. Analysis of the $V$. harveyi HY01 genome revealed a $V$. cholerae like-hemolysin gene, hlyA (designated as hhl). Specific primers designed for $h h l$ detected this gene in 3 additional $V$. harveyi isolates but the presence of this gene was not correlated with pathogenicity. Random amplified polymorphic DNA (RAPD) analysis revealed a high degree of genetic diversity in all $V$. harveyi isolates, and there were no correlations among the hhl-positive isolates or the pathogenic strains.
\end{abstract}

KEY WORDS: Vibrio harveyi $\cdot$ Type III secretion system $\cdot$ TTSS $\cdot v c r D \cdot v h h \cdot h h l \cdot$ Random amplified polymorphic DNA analysis · RAPD

\section{INTRODUCTION}

Many bacteria of the genus Vibrio, including $V$. cholerae, $V$. parahaemolyticus, $V$. vulnificus, $V$. anguillarum, and $V$. mimicus, possess hemolysins (Zhang \& Austin 2005). Most of these hemolysins have been reported to be important virulence factors and some hemolysin genes have only been detected in pathogenic strains (Miyamoto et al. 1969, Honda et al. 1988). V. harveyi is a halophilic bacterium widely distributed in marine environments. It is a causative agent of luminous vibriosis and causes major economic losses in the shrimp farming industry worldwide (Lavilla-Pitogo et al. 1990, Karunasagar et al. 1994, Saeed 1995). Differences in pathogenicity between isolates of $V$. harveyi have been reported, and the role of hemolysins in the virulence of V. harveyi has not been fully determined. V. harveyi isolated from diseased penaeids were more virulent to tiger prawns and showed higher hemolytic activities 
against sheep and fish erythrocytes compared with non-virulent isolates from sea water or diseased Talorchestia sp. (Liu et al. 1996). Investigations of the pathogenicity of $V$. harveyi isolates in fish (Atlantic salmon and rainbow trout) have demonstrated that both pathogenic and non-pathogenic $V$. harveyi isolates induced hemolysis against erythrocytes from sheep, rabbit, donkey, and horse, and the presence of the hemolysin gene vhh has been demonstrated in $V$. harveyi (Zhang \& Austin 2000, Zhang et al. 2001). An investigation of the mortality of Artemia franciscana nauplii after inoculation with $V$. harveyi isolates from healthy and diseased penaeid shrimp from Asia and the Americas indicated that particular exoenzymes were associated with virulent strains (Soto-Rodriguez et al. 2003). No correlation between the hemolytic activity against sheep erythrocytes and the death of infected shrimps was detected (Soto-Rodriguez et al. 2003). Further research is needed to resolve these controversies between the pathogenicity of $V$. harveyi and its ability to cause hemolysis.

Recent studies have shown that many bacteria use a cell-cell communication process known as quorum sensing to control cell population density and ensure that a sufficient number of bacteria are present to coordinate a virulence response that will overwhelm host defenses (Miller \& Bassler 2001, Winzer \& Williams 2001). Quorum sensing has a role in bacterial pathogenicity as it regulates the secretion of virulence factors and biofilm formation (Miller \& Bassler 2001, Donabedian 2003). Quorum sensing has been reported in Vibrio fisheri, $V$. cholerae, V. parahaemolyticus, and V. harveyi (Stevens \& Greenberg 1997, Cámara et al. 2002, Henke \& Bassler 2004a). The virulence of $V$. harveyi may be controlled by a quorum sensing mechanism involving the type III secretion system (TTSS) (Henke \& Bassler 2004a). TTSS is a bacterial system that transfers effector virulence proteins across the membrane of the bacterial pathogen into the cytoplasm of the host cell and has a crucial role in host-pathogen interactions. TTSS is found in many Gram-negative bacteria including $V$. parahaemolyticus, V. alginolyticus, V. cholerae, and V. harveyi (Makino et al. 2003, Park et al. 2004, Dziejman et al. 2005). The TTSS gene cluster in $V$. harveyi includes vop, VSC, and $V C r$, which encode a Vibrio outer membrane protein, Vibrio secretion protein, and Vibrio calcium response protein, respectively (Henke \& Bassler 2004b). vcrD is homologous to the low calcium response gene $\operatorname{lcr} D$, a conserved gene encoding an essential component of the secretion apparatus in Yersinia spp., and lcrD homologs are present in all known TTSSs (Hueck 1998). In the present study, we investigated the correlations between $V$. harveyi pathogenicity in a shrimp model, hemolysis, hemolysin genes, and $v c r D$, a gene involved in the TTSS of $V$. harveyi.

\section{MATERIALS AND METHODS}

Bacterial isolates. Vibrio harveyi HY01 was isolated from a black tiger shrimp that died from luminous vibriosis in Hat Yai city, Thailand. A total of $36 \mathrm{~V}$. harveyi isolates were obtained from fish, shrimp, and mollusks in the same city (Thaithongnum et al. 2006). These isolates were identified by biochemical testing and confirmed by PCR targeted to the DNA gyrase subunit B $($ gyrB) gene. An ocean isolate of $V$. harveyi BAA-1116 (BB210) (Bassler et al. 1997) was provided by Prof. John Mekalanos, Department of Microbiology and Molecular Genetics, Harvard University, USA. The standard strain of $V$. harveyi was obtained from the National Institute of Coastal Aquaculture (NICA), Thailand. V. carchariae, V. cholerae O1, V. cholerae non-O1, V. parahaemolyticus, $V$. vulnificus, V. alginolyticus, V. campbellii, V. furnissii, V. fluvialis, V. hollisae (Grimontia hollisae) and Escherichia coli were from our laboratory stock strains. All bacterial strains were kept at $-80^{\circ} \mathrm{C}$ and were grown overnight on Luria-Bertani (LB) agar containing $1 \% \mathrm{NaCl}$ at $30^{\circ} \mathrm{C}$ before being assayed.

Virulence investigation in vivo. The median lethal dose $\left(\mathrm{LD}_{50}\right)$ of Vibrio harveyi HY01 pathogenic strain and an ocean isolate of $V$. harveyi BAA-1116 was evaluated on the black tiger shrimp Penaeus monodon. The test strains were grown overnight in tryptic soy broth containing $1 \% \mathrm{NaCl}$ at $30^{\circ} \mathrm{C}$ with shaking at $150 \mathrm{rpm}$. Cultured cells were harvested by centrifugation at $200 \times g$ for $10 \mathrm{~min}$, and washed twice with sterile artificial sea water (ASW) (Marinum). Bacterial cell suspensions in ASW were adjusted to $2.5 \times 10^{8}$ colonyforming units (CFU) $\mathrm{ml}^{-1}$ using a turbiditometer (Oxoid) and 2-fold dilutions were performed to obtain concentrations of bacteria between $4.0 \times 10^{5}$ and $6.4 \times$ $10^{6} \mathrm{CFU}$.

The Penaeus monodon juvenile shrimps used in the present study were 10 to $13 \mathrm{~g}$ in weight and 4 to 5 inches $(10.2$ to $12.7 \mathrm{~cm})$ in length. Each shrimp received an intramuscular injection of $0.1 \mathrm{ml}$ diluted Vibrio harveyi (with batches of 7 shrimps dose $^{-1}$ ) between the third and fourth abdominal segments. Control shrimps were injected with ASW. The experiments were performed in duplicate. Shrimps were maintained in a $70 \mathrm{l}$ ASW glass tank at a temperature of $29 \pm 1^{\circ} \mathrm{C}$ and salinity of $17 \mathrm{ppt}$. Shrimp mortalities were observed within $48 \mathrm{~h}$ of injection and were confirmed by detecting luminescence in the organs of the dead shrimp. The $\mathrm{LD}_{50}$ of $V$. harveyi was calculated using the method of Reed \& Muench (1938). 
For evaluation of virulence of all Vibrio harveyi isolates obtained from fish and shellfish, each isolate was injected into shrimps at a concentration of $4 \times \mathrm{LD}_{50}$ (Kashef et al. 2006), using the same procedure as described in the previous paragraph. Mortality rates were measured $48 \mathrm{~h}$ after injection.

Hemolysis detection. Prawn blood agar was prepared according to the technique of Chang et al. (2000). Briefly, $1 \mathrm{ml}$ of citrate-EDTA prawn hemolymph was mixed with Rose Bengal (at a final concentration of $0.3 \% \mathrm{w} / \mathrm{v}$ ) and was added to $15 \mathrm{ml}$ basal medium (consisting of $10 \mathrm{~g}$ Bacto peptone, $10 \mathrm{~g} \mathrm{NaCl}$, and $15 \mathrm{~g}$ Bacto agar in 1 l). Hemolysis was evaluated by detection of a clear zone around Vibrio harveyi colonies on prawn blood agar within $7 \mathrm{~d}$ of incubation at $30^{\circ} \mathrm{C}$.

Testing for hemolysin and TTSS genes. vhh-F and vhh-R primers specific to the vhh hemolysin gene of Vibrio harveyi were designed using vhh sequences of $V$. harveyi VIB 645 (accession nos. AF 293430 and AF 293431) and $V$. harveyi BAA-1116 (accession no. NC_009784) reported in GenBank. vcrD1 and vcrD2 primers targeted to the $\operatorname{vcrD}$ gene, a gene of the TTSS of $V$. harveyi, were designed based on the $\operatorname{vcr} D$ nucleotide sequences of $V$. parahaemolyticus (accession no. NP_798041), V. alginolyticus (accession no. ZP_01259742), and V. campbellii (accession no. ZP_02195895) deposited in GenBank. All primers were designed using MacVector 9.5.2 and BLAST software (www.ncbi.nlm.nih.gov/BLAST/), and are shown in Table 1. To evaluate the specificity of these primers, $V$. harveyi NICA, V. harveyi HY01, V. carchariae, $V$. cholerae O1, V. cholerae non-O1, V. parahaemolyticus, $V$. vulnificus, $V$. alginolyticus, $V$. campbellii, V. furnissii, $V$. fluvialis, $V$. hollisae, and Escherichia coli were grown overnight in LB broth containing $1 \%$ $\mathrm{NaCl}$, and DNA templates were extracted by boiling (Thaithongnum et al. 2006). PCR analysis was performed in $20 \mu \mathrm{l}$ of reaction mixture containing $2 \mu \mathrm{l}$ of $10 \times$ PCR buffer (Promega), $1.5 \mu \mathrm{l}$ of template DNA, $1.6 \mu \mathrm{l}$ of $25 \mathrm{mM} \mathrm{MgCl}_{2}, 5 \mu \mathrm{l}$ of $v h h-\mathrm{F}$ and $v h h-\mathrm{R}$ or vcrD1 and vcrD2 primers $(2 \mu \mathrm{M}), 0.1 \mu \mathrm{l}$ of Taq poly-

Table 1. Primers used for detecting vhh, vcrD, and hhl genes in Vibrio harveyi. $\mathrm{W}=\mathrm{A}$ or $\mathrm{T} ; \mathrm{R}=\mathrm{A}$ or $\mathrm{G}$

\begin{tabular}{|llcc|}
\hline Primer & Primer sequence 5' $\rightarrow 3^{\prime}$ & Position & $\begin{array}{c}\text { Product } \\
\text { size (bp) }\end{array}$ \\
\hline$v h h-F$ & AAGTAATCAGCAGCAGACGAGCG & $3006-3919$ & 914 \\
$v h h-R$ & GAGTGGGCAGAAAATCCAGATGG & & \\
$v c r D 1$ & TGWRACACGGGTAACGATGA & $1333-1664$ & 332 \\
$v c r D 2$ & GTAAGCAGATGAGRATCGACGG & & 1019 \\
$h h l-F$ & TTCAGAAAGACTTATGGGCTGGG & $2287-3305$ & \\
$h h l-R$ & TAAACACCGTGATAGATTGGGCG & & \\
\hline
\end{tabular}

merase (Promega), and $1.6 \mu \mathrm{l}$ of $2.5 \mathrm{mM}$ dNTPs. PCR analysis was performed using a Gene Amp PCR thermocycler, and the reaction involved $96^{\circ} \mathrm{C}$ for $5 \mathrm{~min}$, 35 cycles of $94^{\circ} \mathrm{C}$ for $1 \mathrm{~min}, 56^{\circ} \mathrm{C}$ for $1 \mathrm{~min}$, and $72^{\circ} \mathrm{C}$ for $1 \mathrm{~min}$, followed by $72^{\circ} \mathrm{C}$ for $7 \mathrm{~min}$. The amplification products were subjected to electrophoresis in $1 \%$ agarose gel.

A total of 38 isolates of Vibrio harveyi were examined for the presence of $v h h$ and $v c r D$. Southern-blot hybridization assays were used to confirm isolates that were PCR-negative for vhh (Bhoopong et al. 2007). Briefly, genomic DNA from $V$. harveyi was digested with ECoRI restriction enzyme, the vhh probe was prepared by PCR using the vhh primers designed in the previous paragraph, and the probe was labeled with digoxigenin. Hybridization was performed under highstringency conditions at $42^{\circ} \mathrm{C}$. The hybridized probes were detected using a DNA detection kit (Roche Diagnostics) according to the manufacturer's instructions.

hlyA-like hemolysin gene. Using BLAST software, a sequence alignment of the hemolysin gene from Vibrio harveyi strain HY01 (GenBank accession no. NZ_AAWP01000001) showed 86\% homology to the hlyA hemolysin gene of V. cholerae N16961 (GenBank accession no. AE003853). Therefore, specific primers for this gene, designated as $h h l$, were designed (Table 1). Amplification conditions for this gene were similar to those used for $\operatorname{vcrD}$, except that $1 \mu \mathrm{l}$ of each primer ( $2 \mu \mathrm{M}$ concentration) was used and the PCR reaction comprised $94^{\circ} \mathrm{C}$ for $5 \mathrm{~min}, 30$ cycles of $94^{\circ} \mathrm{C}$ for $45 \mathrm{~s}, 50^{\circ} \mathrm{C}$ for $1 \mathrm{~min}$, and $72^{\circ} \mathrm{C}$ for $1 \mathrm{~min}$. The presence of this $h$ hl gene was examined in $V$. harveyi HY01 and $V$. harveyi BAA-1116, and 36 isolates of $V$. harveyi from fish and shellfish. Some hhl-negative isolates were confirmed by Southern-blot hybridization using the $h$ hl probe.

Random amplified polymorphic DNA (RAPD) fingerprinting. To characterize DNA profiles of pathogenic and non-pathogenic strains of Vibrio harveyi, genomic DNA of $V$. harveyi was extracted by a phenolchloroform method and RAPD was performed using the RAPD universal primer 2 (5'-GTT TCG CTC C-3') (Radu et al. 1998, Wootipoom et al. 2007). Amplification was performed in a $30 \mu \mathrm{l}$ mixture containing $0.33 \mathrm{mM}$ dNTPs (TaKaRa Biochemicals), $25 \mathrm{ng}$ of template DNA, 2.5 U Ex Taq (TaKaRa), 0.83 pmol of primer, and $1 \times$ buffer. The PCR analysis was performed in an Astec PC818A thermal cycler and the reaction comprised $95^{\circ} \mathrm{C}$ for $4 \mathrm{~min}, 45$ cycles of denaturation at $95^{\circ} \mathrm{C}$ for $1 \mathrm{~min}$, annealing at $36^{\circ} \mathrm{C}$ for $1 \mathrm{~min}$, and extension at $72^{\circ} \mathrm{C}$ for $2 \mathrm{~min}$, followed 
by $72^{\circ} \mathrm{C}$ for $7 \mathrm{~min}$. The amplification products were analyzed by electrophoresis using a $1.5 \%$ agarose gel.

Using a Bioprofile image analysis system (Viber Lourmat), a dendrogram was constructed using the data matrix generated by the DNA profiles of all 38 tested strains of Vibrio harveyi (Sneath \& Sokal 1973).

Table 2. Investigation of the median lethal dose $\left(\mathrm{LD}_{50}\right)$ of $V i b$ rio harveyi strains HY01 and BAA-1116 in Penaeus monodon. Experiments were performed in duplicate, and \% mortality of shrimps in both experiments was not different. Therefore, the results of 1 experiment are shown here. CFU = colonyforming unit

\begin{tabular}{|lcrrr|}
\hline $\begin{array}{l}\text { V. harveyi strain } \\
\text { Dose (CFU } \\
\text { shrimp }\end{array}$ & $\begin{array}{c}\text { No. of } \\
\text { shrimp } \\
\text { dead/total }\end{array}$ & $\begin{array}{l}\text { Cumulative } \\
\text { no. shrimp } \\
\text { Dead }\end{array}$ & $\begin{array}{c}\text { Mortality } \\
(\%)\end{array}$ \\
\hline HY01 & & & & \\
$6.4 \times 10^{6}$ & $5 / 7$ & 12 & 2 & 85.7 \\
$3.2 \times 10^{6}$ & $4 / 7$ & 7 & 5 & 58.3 \\
$1.6 \times 10^{6}$ & $3 / 7$ & 3 & 9 & 25.0 \\
$8.0 \times 10^{5}$ & $0 / 7$ & 0 & 16 & 0 \\
$4.0 \times 10^{5}$ & $0 / 7$ & 0 & 23 & 0 \\
BAA-1116 & & & & \\
$6.4 \times 10^{6}$ & $0 / 7$ & 0 & 7 & 0 \\
$3.2 \times 10^{6}$ & $0 / 7$ & 0 & 7 & 0 \\
$1.6 \times 10^{6}$ & $0 / 7$ & 0 & 7 & 0 \\
$8.0 \times 10^{5}$ & $0 / 7$ & 0 & 7 & 0 \\
$4.0 \times 10^{5}$ & $0 / 7$ & 0 & 7 & 0 \\
\hline
\end{tabular}

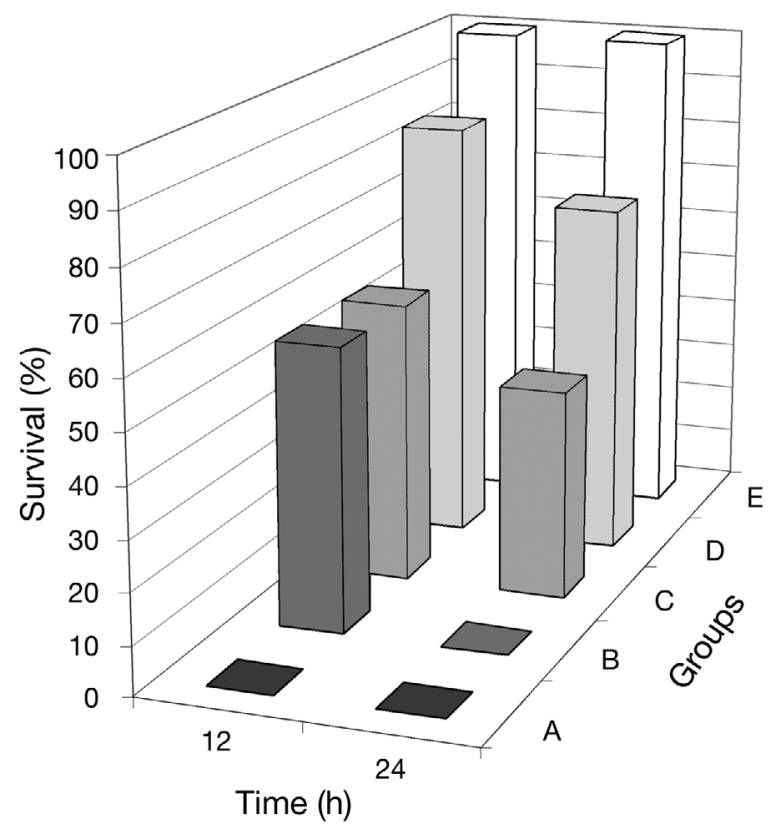

Fig. 1. Survival of Penaeus monodon after injection with Vibrio harveyi isolates. See Table 3 for Groups A to E. In the control group (not shown), none of the shrimp died after injection with artificial sea water (ASW)
Statistical analysis. Pearson's correlation coefficient was used to investigate correlations between hemolytic activity and shrimp mortality (Neter et al. 1996).

\section{RESULTS}

\section{Determination of shrimp pathogenicity}

The $\mathrm{LD}_{50}$ of Vibrio harveyi was evaluated using $V$. harveyi strains HY01 and BAA-1116. Mortality rates of 85.7 and $58.3 \%$ were observed in injected shrimp after

Table 3. Detection of hemolysis and $v c r D, v h h$, and hhl genes in Vibrio harveyi isolates. +: detected; -: not detected

\begin{tabular}{|c|c|c|c|c|c|}
\hline \multirow{2}{*}{$\begin{array}{l}\text { Isolate } \\
\text { no. pr } \\
4\end{array}$} & \multirow{2}{*}{$\begin{array}{c}\text { Hemolysis on } \\
\text { prawn blood agar } \\
+\end{array}$} & \multicolumn{3}{|c|}{$\begin{array}{l}\text { PCR detection of } \\
\text { vcrD vhh hhl }\end{array}$} & \multirow{2}{*}{$\begin{array}{c}\text { Group } \\
\mathrm{A}\end{array}$} \\
\hline & & + & + & - & \\
\hline 7 & + & + & + & - & $\mathrm{A}$ \\
\hline 23 & + & + & + & - & $\mathrm{A}$ \\
\hline 25 & + & + & + & - & A \\
\hline 26 & + & + & + & - & A \\
\hline 30 & + & + & + & - & A \\
\hline 33 & + & + & + & - & A \\
\hline 34 & + & + & + & - & A \\
\hline 9 & - & + & + & - & A \\
\hline 1 & + & - & - & - & A \\
\hline 2 & + & - & + & - & A \\
\hline 18 & + & - & - & - & A \\
\hline 8 & + & + & - & - & $\mathrm{B}$ \\
\hline 19 & + & + & + & - & $\mathrm{B}$ \\
\hline 20 & + & + & + & - & B \\
\hline 21 & + & + & + & - & B \\
\hline 27 & + & + & + & - & B \\
\hline 31 & + & + & + & - & B \\
\hline 32 & + & + & + & - & B \\
\hline 36 & + & + & + & - & B \\
\hline 15 & - & + & + & + & B \\
\hline 17 & + & + & + & - & B \\
\hline 14 & - & + & + & - & $\mathrm{B}$ \\
\hline 16 & + & + & + & - & $\mathrm{C}$ \\
\hline 22 & + & + & + & - & $\mathrm{C}$ \\
\hline 29 & + & + & + & - & $\mathrm{C}$ \\
\hline 12 & - & + & + & - & C \\
\hline 13 & - & + & + & - & $\mathrm{C}$ \\
\hline 24 & - & + & - & - & $\mathrm{C}$ \\
\hline 6 & + & + & + & - & $\mathrm{C}$ \\
\hline 28 & + & + & + & - & $\mathrm{C}$ \\
\hline 35 & + & + & + & - & $\mathrm{C}$ \\
\hline 5 & + & + & + & + & $\mathrm{D}$ \\
\hline 3 & + & + & + & - & $\mathrm{D}$ \\
\hline 10 & - & + & + & - & $\mathrm{D}$ \\
\hline 11 & - & + & + & + & $\mathrm{D}$ \\
\hline HY01 & + & + & + & + & $\mathrm{A}$ \\
\hline BAA-1116 & $-{ }^{a}$ & + & + & - & $\mathrm{E}$ \\
\hline
\end{tabular}

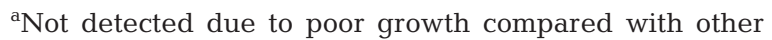
strains tested on the same prawn blood agar plates after $7 \mathrm{~d}$ of incubation 
injection of $V$. harveyi HY01 at concentrations of $6.4 \times 10^{6}$ and $3.2 \times 10^{6} \mathrm{CFU}$ shrimp $^{-1}$, respectively (Table 2 ). No shrimp deaths were detected after injection of $V$. harveyi BAA-1116. Therefore, the $\mathrm{LD}_{50}$ of $V$. harveyi HY01 was calculated to be $1.9 \times 10^{6} \mathrm{CFU}$ shrimp $^{-1}$. Inoculum concentrations equivalent to $4 \times \mathrm{LD}_{50}$ were used to analyze the pathogenicity of $38 \mathrm{~V}$. harveyi isolates. We classified the $V$. harveyi isolates into 5 groups (A to E) according to their ability to cause shrimp death within a certain time period post-injection, with Group A being the most pathogenic and Group E the least. Thirteen isolates of $V$. harveyi were classified in Group A, including V. harveyi HY01 (Fig. 1, Table 3), because they were the most pathogenic strains, inducing $100 \%$ mortality within $12 \mathrm{~h}$ of injection. No live shrimp were detected at $24 \mathrm{~h}$ after injection with isolates of Group B (11 isolates). $V$. harveyi isolates of Group C (9 isolates) induced $58 \%$ mortality among test shrimp by $24 \mathrm{~h}$ after injection, with no subsequent deaths. The isolates designated as belonging to Group D (4 isolates) caused $29 \%$ mortality within $24 \mathrm{~h}$ of injection with no subsequent mortality thereafter. None of the shrimp died after injection with $V$. harveyi BAA-1116, which was designated as Group E.

\section{Detection of hemolysis}

Hemolysis on prawn blood agar was evaluated for all Vibrio harveyi isolates. It is of interest that 12 of the 13 $V$. harveyi isolates (92.3\%) in Group A, including $V$. harveyi HY01, caused hemolysis, whereas the hemolytic activity of isolates of Groups B, C, and D was 81.8, 66.7 , and $50.0 \%$, respectively (Table 3 ). No hemolysis was observed on prawn blood agar inoculated with $V$. harveyi BAA-1116.

\section{Detection of vhh and vcrD genes}

The specificities of the vhh and $\operatorname{vcrD}$ primers (Table 1) were evaluated using 2 strains of Vibrio harveyi, 9 species of Vibrio, and Escherichia coli. Only $V$. harveyi produced an amplicon with the vhh primers (Fig. 2). For the $\operatorname{vcr} D$ primers, only $V$. harveyi, $V$. carchariae, and $V$. parahaemolyticus gave a positive result with a single 332 bp DNA product.
This result was not surprising because previous analysis of $16 \mathrm{~S}$ ribosomal DNA sequences has indicated that $V$. carchariae is the junior synonym of $V$. harveyi (Gauger \& Gómez-Chiarri 2002), and the sequence, organization, and regulation of the TTSS gene clusters in $V$. harveyi and $V$. parahaemolyticus have been reported to be similar (Henke \& Bassler 2004a).

All 38 isolates of Vibrio harveyi were analyzed for the presence of the vhh and vcrD genes using PCR. $\operatorname{vcrD}$ was detected in $35 \mathrm{~V}$. harveyi isolates $(91.7 \%)$, but not among isolate numbers 1, 2, and 18 (Table 3). vhh was detected in 34 isolates (89.5\%) and negative in the remaining 4 isolates (isolate numbers 1, 18, 8 , and 24).

\section{Detection of the $h h l$ gene}

The hhl gene was detected in 3 isolates of Vibrio harveyi (isolate numbers 15, 5, and 11) obtained from fish and shellfish (Table 3 ). These 3 isolates and $V$. harveyi HY01 contained both vhh and hhl hemolysin genes. Interestingly, 3 isolates that were negative for both vhh and hhl (isolate numbers 1, 18, and 8) showed hemolytic activity against prawn erythrocytes (Table 3). Therefore, Southern-blot hybridization was performed using the vhh and hhl probes (Fig. 3), and these isolates (plus isolate number 24) were shown to be vhh-positive (Fig. 3a). 
a

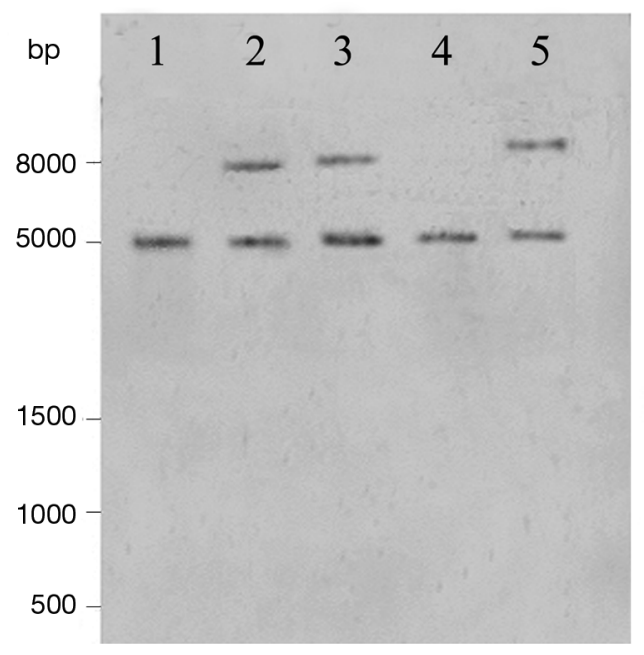

b

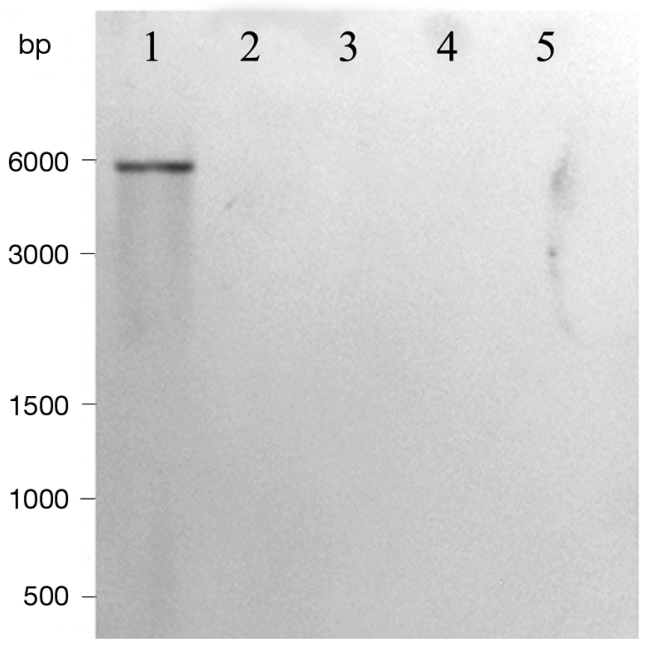

Fig. 3. Southern-blot hybridization analysis to detect (a) vhh and (b) hhl genes in Vibrio harveyi. Genomic DNA was digested with EcoRI and hybridized with (a) a $914 \mathrm{bp} v h h$-specific probe and (b) a $1019 \mathrm{bp}$ hhl-specific probe under high stringency conditions. Lane 1: $V$. harveyi HY01; Lanes 2 to 5, in order: $V$. harveyi isolates 1, 8, 18, and 24 (molecular weight markers: 1 kb DNA ladder, New England Biolabs)

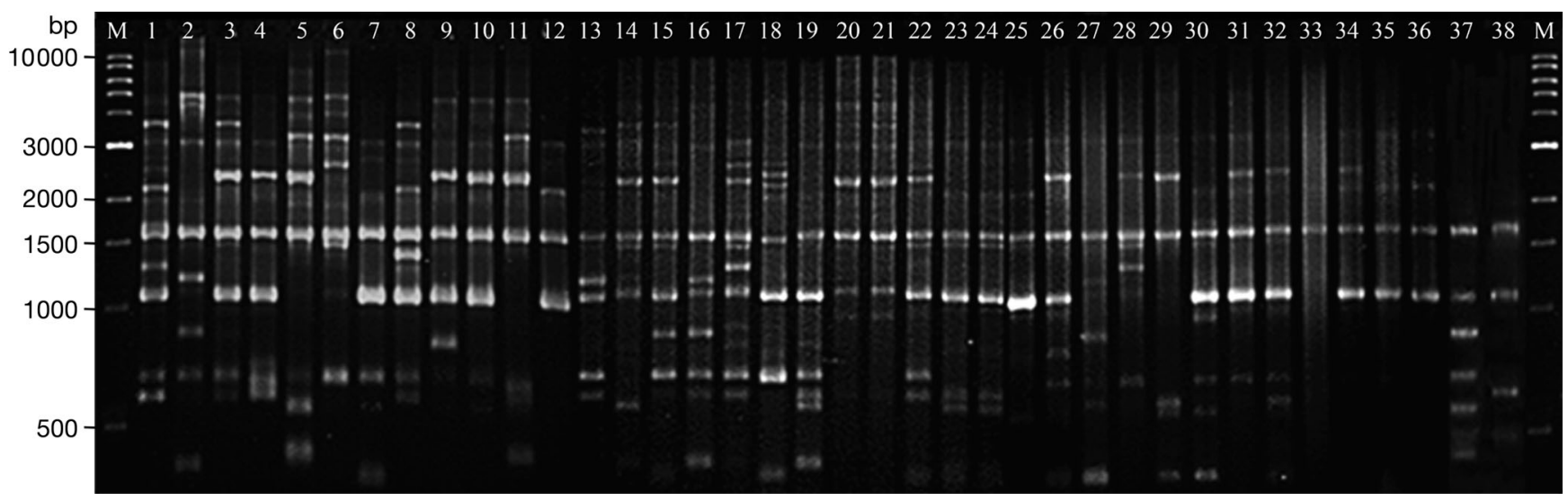

Fig. 4. Random amplified polymorphic DNA (RAPD) profiles of 38 Vibrio harveyi isolates. Lanes 1 to 36: each lane number is correlated to the isolate number of $V$. harveyi listed in Table 3; Lanes 37 and 38: $V$. harveyi HY01 and V. harveyi BAA-1116, respectively. Molecular weight markers (M): $1 \mathrm{~kb}$ DNA ladder (New England Biolabs)

\section{RAPD fingerprinting}

DNA fingerprinting of all Vibrio harveyi isolates was performed using the RAPD technique. Analysis of DNA profiles revealed 1 to 27 amplicons ranging from 300 to $12000 \mathrm{bp}$. Although all of the isolates shared one $1600 \mathrm{bp}$ amplicon, 16 distinctive DNA profiles at $70 \%$ similarity were observed (Figs. 4 \& 5). V. harveyi HY01 and all $3 \mathrm{~V}$. harveyi isolates with $h \mathrm{hl}$ showed different DNA profiles.

\section{DISCUSSION}

Some virulence factors of pathogenic strains of Vibrio harveyi have not been fully investigated. In the present study, we evaluated the pathogenicity of 38 isolates of $V$. harveyi in a shrimp model and investigated their ability to cause hemolysis on prawn blood agar, including the presence of hemolysin genes and a gene involved in TTSS. Chang et al. (2000) previously demonstrated that prawn blood agar was a better 


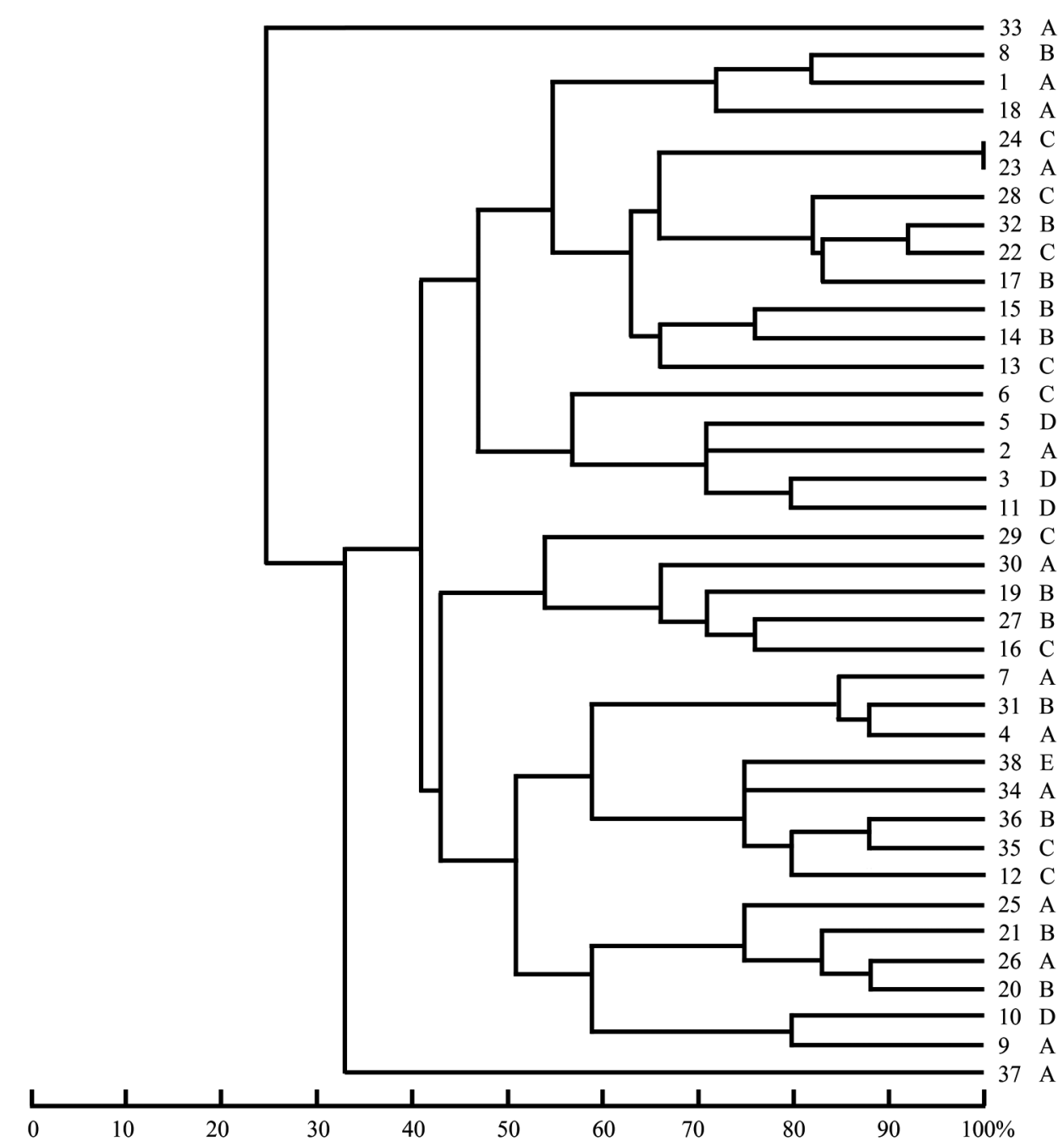

Fig. 5. A dendrogram constructed from random amplified polymorphic DNA (RAPD) profiles of 38 Vibrio harveyi isolates. Numbers 1 to 36: each lane number is correlated to the $V$. harveyi isolate number given in Table 3 and Fig. 4 . Numbers 37 and 38 : $V$. harveyi HY01 and $V$. harveyi BAA-1116, respectively. A, B, C, D, and E indicate the groups of $V$. harveyi listed in Table 3

model than sheep blood agar for screening pathogenic bacteria isolated from tiger prawns and for observing correlations between their ability to cause shrimp death and hemolysis. In the present study, 12 of $13 \mathrm{~V}$. harveyi isolates $(92.3 \%)$ in Group A (Table 3) produced hemolysis on prawn blood agar, and this group caused all shrimps to die within $12 \mathrm{~h}$ of injection. $V$. harveyi HY01 isolated from a shrimp that had died from luminous vibriosis was also classified in this group. However, 81.8, 66.7, and $50.0 \%$ of $V$. harveyi isolates in Groups B, C, and D, respectively, displayed hemolytic activity on prawn blood agar, and these isolates were less virulent in the shrimp model (Fig. 1). No shrimp deaths were detected after injection with $V$. harveyi BAA-1116 (Group E), and this strain caused no hemolysis and exhibited poor growth on prawn blood agar after $7 \mathrm{~d}$ of incubation. It is possible that this strain was sensitive to the Rose Bengal used in the plate medium. Evaluation of the correlation between the hemolytic activity of $V$. harveyi and the deaths of infected shrimps by Pearson's correlation coefficient analysis (r) demonstrated a significant correlation at $24 \mathrm{~h}$ after infection $(\mathrm{r}=0.972, \mathrm{p}<0.05)$. Therefore, the presence of $V$. harveyi hemolysin genes was evaluated. Thirty-four isolates of $V$. harveyi, including $V$. harveyi HY01 and BAA-1116, were shown to be positive for vhh by PCR, and the remaining 4 isolates (numbers $1,18,8$, and 24 ) were shown to be vhh-positive by Southern-blot hybridization (Fig. 3a). Different nucleotide sequences in this gene that did not correspond to the target sequences of the vhh PCR primers may be the reason why these 4 isolates produced a 
negative result in the PCR assay. The Southern-blot hybridization results indicated that there were 1 or 2 copies of vhh in these 4 isolates, which correlates with the report of Zhang et al.(2001), who demonstrated duplicate vhh genes, designated as vhhA and $v h h B$, in $V$. harveyi isolates. However, most isolates examined contained only a single gene, and vhhA and vhhB were shown to have $98.8 \%$ homology (Zhang et al.2001).

It is of interest that vhh was detected in all Vibrio harveyi isolates but some isolates (isolate numbers 9 , $15,14,12,13,24,10$, and 11) did not show hemolysis on prawn blood agar. This indicates that in some isolates there may be unknown factors that control gene expression and hemolysin production. Zhang \& Austin (2000) demonstrated that different strains of $V$. harveyi produce different amounts of hemolysin against erythrocytes of salmon, trout, sheep, rabbit, donkey, and horse. Although hemolysin production against salmon erythrocytes from some isolates had a titer of $1: 8$ to $1: 16$ and caused 20 to $40 \%$ mortality in rainbow trout, $1 V$. harveyi isolate with the highest titer $(1: 256)$ caused $60 \%$ mortality in rainbow trout. Future work to investigate factors that can affect vhh gene expression may clarify the correlation between the amount of hemolysin produced and the pathogenicity of $V$. harveyi.

We also found that Vibrio harveyi HY01 contains hhl, which has a sequence similar to the hlyA gene of $V$. cholerae. Therefore, specific primers were designed to detect this gene in other $V$. harveyi isolates. hhl was detected in only a few strains of $V$. harveyi and the positive isolates were not classified into Group A, the most pathogenic group (Table 3). Southern-blot hybridization results confirmed that the isolates shown to be hhlnegative by PCR did not possess this gene (Fig. 3b). These results indicate that $h h l$ is not conserved in $V$. harveyi and might not be a $V$. harveyi virulence determinant. Several hemolysin genes similar to hlyA have been reported in Vibrio spp.; for example, most clinical and environmental isolates of $V$. mimicus possess $v m h$ (Shinoda et al. 2004), and vvh and vahl have been detected in most isolates of $V$. vulnificus and $V$. anguillarum, respectively (Hirono et al. 1996, Aono et al. 1997). Nucleotide sequence analysis of HY01 hhl and hlyA genes of $V$. cholerae N16961 (GenBank accession no. AE003853) and $V$. cholerae N86 (GenBank accession no. X51746), vmh genes of $V$. mimicus ATCC33653 (GenBank accession no. U68271), vahl genes of $V$. anguillarum PT84057 (GenBank accession no. S83534), and vvh genes of $V$. vulnificus EDL174 (GenBank accession no. M34670) revealed 86, 86.8, 73, 68.9 , and $41 \%$ identity, respectively. Therefore, it is possible that the $h h l$ detected in a few isolates of $V$. harveyi in the present study might be derived from $V$. cholerae as a discrete genetic unit by horizontal gene transfer. Further analysis of any mobile genetic elements closely associated with $h$ hl may clarify how this gene has appeared in some $V$. harveyi isolates.

Several extracellular products (ECPs), such as a cysteine protease, have been reported in Vibrio harveyi (Liu \& Lee 1999). Secretion of these ECPs may be controlled through a TTSS that has been detected in many pathogenic bacteria such as Yersinia spp., Shigella spp., Salmonella spp., Pseudomonas spp., and some species of Vibrio (Galan \& Collmer 1999, Makino et al. 2003, Dziejman et al. 2005). Park et al. (2004) demonstrated that the TTSSs detected in $V$. parahaemolyticus are involved in cytotoxicity and enterotoxicity. In the present study, $\operatorname{vcr} D$, a gene involved in the TTSS of $V$. harveyi, was examined. As it was detected in all isolates of $V$. harveyi except 3 isolates of Group A (Table $3)$, we concluded that $\operatorname{vcr} D$ might not be correlated with the pathogenicity of $V$. harveyi in shrimp. The presence of this gene may relate to its persistence in the environment. By hybridization analysis using probes of the $V$. cholerae secretion genes ( $\mathrm{vCS} V 2$, ${ }_{V C S N}$, and ${ }^{2} C S C 2$ ) and the $V$. cholerae secreted protein gene ( $v s p D$ ), Rahman et al. (2008) found that TTSS was not detected in most clinical isolates of $V$. cholerae O1 and O139, but was present in $11.9 \%$ of environmental isolates of $V$. cholerae non-O1 and non-O139. This indicates that, in some bacteria, TTSSs might have functions in the environment.

RAPD-PCR has been reported to be a useful technique for distinguishing Vibrio harveyi isolates (Hernández \& Olmos 2004). In the present study, RAPD analysis of the $38 \mathrm{~V}$. harveyi isolates in Groups A to $\mathrm{E}$ showed a high degree of genetic diversity and no correlation was detected between DNA profiles of pathogenic and non-pathogenic isolates. This may be because this organism is present in many marine environments and therefore has become associated with a range of animals and environmental factors. As a result, to ensure survival in these diverse habitats, isolates have acquired a range of genes, resulting in the diverse RAPD profiles. Four isolates of $V$. harveyi that possess $h h l$ produced different RAPD profiles, which indicates that they are of unrelated origins.

In conclusion, we evaluated the mortality of shrimps infected with Vibrio harveyi isolates obtained from fish and shellfish, including 1 isolate (HY01) obtained from a dead shrimp and another (BAA-1116) obtained from sea water, and demonstrated correlations between the isolates that showed hemolytic activity on prawn blood agar and the ability to cause shrimp death. Although vhh was detected in all isolates of $V$. harveyi, some isolates showed no hemolytic activity. This indicates that some as-yet-unknown factors might be involved in regulating gene expression. A $V$. cholerae hlyA-like 
gene, not previously reported in $V$. harveyi, was detected in $4 \mathrm{~V}$. harveyi isolates including $V$. harveyi HY01. However, the presence of this gene, including a TTSS gene, $\operatorname{vcr} D$, was not related to the death of infected shrimps.

Acknowledgements. This study was supported by funding from the Government of Thailand and the Thailand Research Fund through the Royal Golden Jubilee PhD Program (grant no. PHD/0153/2547). We thank Dr. B. Hodgson for assistance with the manuscript.

\section{LITERATURE CITED}

Aono E, Sugita H, Kawasaki J, Sakakibara H, Takahashi T, Endo K, Deguchi Y (1997) Evaluation of the polymerase chain reaction method for identification of Vibrio vulnificus isolated from marine environments. J Food Prot 60: 81-83

Bassler BL, Greenberg EP, Stervens AM (1997) Cross-species induction of luminescence in the quorum-sensing bacterium Vibrio harveyi. J Bacteriol 179:4043-4045

Bhoopong P, Palittapongarnpim P, Pomwised R, Kiatkittipong A and others (2007) Variability of the properties of Vibrio parahaemolyticus strains isolated from single patients. J Clin Microbiol 45:1544-1550

> Cámara M, Hardman A, Williams P, Milton D (2002) Quorum sensing in Vibrio cholerae. Nat Genet 32:217-218

> Chang CI, Liu WY, Shyu CZ (2000) Use of prawn blood agar hemolysis to screen for bacteria pathogenic to cultured tiger prawns Penaeus monodon. Dis Aquat Org 43: $153-157$

Donabedian H (2003) Quorum sensing and its relevance to infectious diseases. J Infect 46:207-214

Dziejman M, Serruto D, Tam VC, Sturtevant D and others (2005) Genomic characterization of non-O1, non-O139 Vibrio cholerae reveals genes for a type III secretion system. Proc Natl Acad Sci USA 102:3465-3470

Galan JE, Collmer A (1999) Type III secretion machines: bacterial devices for protein delivery into host cells. Science 284:1322-1328

Gauger EJ, Gómez-Chiarri M (2002) 16S ribosomal DNA sequencing confirms the synonymy of Vibrio harveyi and V. carchariae. Dis Aquat Org 52:39-46

> Henke JM, Bassler BL (2004a) Quorum sensing regulates type III secretion in Vibrio harveyi and Vibrio parahaemolyticus. J Bacteriol 186:3794-3805

Henke JM, Bassler BL (2004b) Bacterial social engagements. Trends Cell Biol 14:648-656

> Hernández G, Olmos J (2004) Molecular identification of pathogenic and nonpathogenic strains of Vibrio harveyi using PCR and RAPD. Appl Microbiol Biotechnol 63: $722-727$

> Hirono I, Masuda T, Aoki T (1996) Cloning and detection of the hemolysin gene of Vibrio anguillarum. Microb Pathog 21:173-182

> Honda T, Ni Y, Miwatani T (1988) Purification and characterization of a hemolysin produced by a clinical isolate of Kanagawa phenomenon-negative Vibrio parahaemolyticus and related to the thermostable direct hemolysin. Infect Immun 56:961-965

Hueck CJ (1998) Type III protein secretion systems in bacterial pathogens of animals and plants. Microbiol Mol Biol Rev 62:379-433
Karunasagar I, Pai R, Malathi GR, Karunasagar I (1994) Mass mortality of Penaeus monodon larvae due to antibioticresistant Vibrio harveyi infection. Aquaculture 128: 203-209

Kashef N, Behzadian-Nejad Q, Najar-Peerayeh S, MousaviHosseini K, Moazzeni M, Djavid GE (2006) Synthesis and characterization of Pseudomonas aeruginosa alginatetetanus toxoid conjugate. J Med Microbiol 55:1441-1446

Lavilla-Pitogo CR, Baticados MCL, Cruz-Lacierda ER, de la Pena EL (1990) Occurrence of luminous bacterial disease of Penaeus monodon larvae in the Philippines. Aquaculture 91:1-13

$>$ Liu PC, Lee KK (1999) Cysteine protease is a major exotoxin of pathogenic luminous Vibrio harveyi in the tiger prawn, Penaeus monodon. Lett Appl Microbiol 28:428-430

$>$ Liu PC, Lee KK, Chen SN (1996) Pathogenicity of different isolates of Vibrio harveyi in tiger prawn, Penaeus monodon. Lett Appl Microbiol 22:413-416

Makino K, Oshima K, Kurokawa K, Yokoyama K and others (2003) Genome sequence of Vibrio parahaemolyticus: a pathogenic mechanism distinct from that of $V$. cholerae. Lancet 361:743-749

Miller MB, Bassler BL (2001) Quorum sensing in bacteria. Annu Rev Microbiol 55:165-199

> Miyamoto Y, Kato T, Obara Y, Akiyama S, Takizawa K, Yamai S (1969) In vitro hemolytic characteristic of Vibrio parahaemolyticus: its close correlation with human pathogenicity. J Bacteriol 100:1147-1149

Neter J, Kutner MH, Nachtsheim CJ, Wasserman W (1996) Applied linear statistical models, 4th edn. McGraw-Hill, Chicago, IL

Park KS, Ono T, Rokuda M, Jang MH, Okuda K, Iida T, Honda T (2004) Functional characterization of two type III secretion systems of Vibrio parahaemolyticus. Infect Immun 72:6659-6665

Radu S, Mutalib SA, Rusul G, Ahmad Z and others (1998) Detection of Escherichia coli O157:H7 in the beef marketed in Malaysia. Appl Environ Microbiol 64: 1153-1156

Rahman MH, Biswas K, Hossain MA, Sack RB, Mekalanos JJ, Faruque SM (2008) Distribution of genes for virulence and ecological fitness among diverse Vibrio cholerae population in a cholera endemic area: tracking the evolution of pathogenic strains. DNA Cell Biol 27:347-355

Reed LJ, Muench H (1938) A simple method of estimating fifty percent end point. Am J Hyg 27:493-497

> Saeed MO (1995) Association of Vibrio harveyi with mortalities in cultured marine fish in Kuwait. Aquaculture 136: $21-29$

> Shinoda S, Nakagawa T, Shi L, Bi K and others (2004) Distribution of virulence associated genes in Vibrio mimicus isolates from clinical and environmental origins. Microbiol Immunol 48:547-551

Sneath PHA, Sokal RR (1973) Numerical taxonomy. Freeman, San Francisco, CA

> Soto-Rodriguez SA, Roque A, Lizarraga-Partida ML, GuerraFlores AL, Gomez-Gil B (2003) Virulence of luminous vibrios to Artemia franciscana nauplii. Dis Aquat Org 53: 231-240

Stevens AM, Greenberg EP (1997) Quorum sensing in Vibrio fisheri: essential elements for activation of the luminescence genes. J Bacteriol 179:557-562

Thaithongnum S, Ratanama P, Weeradechapol K, Sukhoom A, Vuddhakul V (2006) Detection of V. harveyi in shrimp postlarvae and hatchery tank water by the Most Probable Number technique with PCR. Aquaculture 261:1-9

Winzer K, Williams P (2001) Quorum sensing and the regula- 
tion of virulence gene expression in pathogenic bacteria. Int J Med Microbiol 291:131-143

Wootipoom N, Bhoopong P, Pomwised R, Nishibuchi M, Ishibashi M, Vuddhakul V (2007) A decrease in the proportion of infections by pandemic Vibrio parahaemolyticus in Hat Yai Hospital, southern Thailand. J Med Microbiol 56:1630-1638

Editorial responsibility: Ken Hasson,

College Station, Texas, USA
Zhang XH, Austin B (2000) Pathogenicity of Vibrio harveyi to salmonids. J Fish Dis 23:93-102

Zhang XH, Austin B (2005) Haemolysins in Vibrio species. J Appl Microbiol 98:1011-1019

Zhang XH, Meaden PG, Austin B (2001) Duplication of hemolysin genes in a virulent isolate of Vibrio harveyi. Appl Environ Microbiol 67:3161-3167

Submitted: June 4, 2009; Accepted: July 22, 2009

Proofs received from author(s): September 10, 2009 